Medical Principles and Practice
Med Princ Pract 2013;22:270-273

DOI: $10.1159 / 000345393$
Received: May 6, 2012

Accepted: October 24, 2012

Published online: December 5, 2012

\title{
Mean Platelet Volume Is Increased in Infective Endocarditis and Decreases after Treatment
}

\author{
Atilla Icli $^{\mathrm{a}}$ Senol Tayyar ${ }^{\mathrm{b}}$ Ercan Varol ${ }^{\mathrm{b}}$ Fatih Aksoy $^{\mathrm{b}}$ Akif Arslan $^{\mathrm{b}}$ \\ Ibrahim Ersoy ${ }^{\text {b Selahaddin Akcay }}{ }^{\text {b }}$

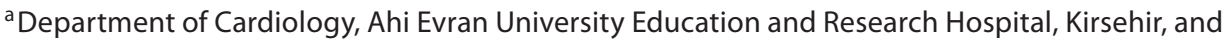 \\ ${ }^{\mathrm{b}}$ Faculty of Medicine, Suleyman Demirel University, Isparta, Turkey
}

\section{Key Words}

Mean platelet volume $\cdot$ Infective endocarditis - Thrombus . Vegetation

\begin{abstract}
Objectives: The aim of this study was to assess the mean platelet volume (MPV), an indicator of platelet activation in patients with infective endocarditis. Subjects and Methods: Twenty-nine patients with infective endocarditis and 29 healthy subjects were studied. Plasma MPV values in patients and control subjects were measured on admission and after 2 weeks of specific treatment of infective endocarditis. Results: The MPV was significantly higher among patients with infective endocarditis when compared with the control group $(9.86 \pm 1.1$ vs. $8.0 \pm 1.0 \mathrm{fl}$, respectively; $\mathrm{p}<0.01)$. The MPV values of patients with infective endocarditis decreased significantly after treatment from $9.86 \pm 1.1$ to $7.86 \pm 1.0 \mathrm{fl}$ $(p<0.01)$. Total platelet counts increased significantly after treatment from $193.4 \pm 96.5 \times 10^{9}$ to $243.7 \pm 92.4 \times 10^{9}$ $(p=0.04)$. Conclusion: MPV values were higher in patients with infective endocarditis and decreased significantly after treatment. Elevated MPV values indicate that patients with infective endocarditis have increased platelet activation and infective endocarditis treatment decreases this platelet activation by decreasing MPV.

Copyright $\odot 2012$ S. Karger AG, Basel
\end{abstract}

\section{KARGER}

E-Mail karger@karger.com www.karger.com/mpp

\section{(c) 2012 S. Karger AG, Basel} 1011-7571/13/0223-0270\$38.00/0

Karge

Open access

This is an Open Access article licensed under the terms of the Creative Commons Attribution-NonCommercial-NoDerivs 3.0 License (www.karger.com/OA-license), applicable to the online version of the article only. Distribution for non-commercial purposes only.

\section{Introduction}

Infective endocarditis remains a diagnostic and therapeutic challenge, as evidenced by the stability of its incidence over time and its morbidity and mortality rates $[1,2]$. Endocardial vegetations can cause direct valvular damage. Embolic events are frequent and represent one of the life-threatening complications of infective endocarditis [3]. The endocardial thrombotic vegetation represents a specific model of pathogen/host tissue interaction, involving the formation of a septic thrombus leading to injury of both underlying valvular and cardiac tissue, and to possible peripheral septic dissemination [4]. Pathogen-platelet molecular interactions are probably one of the main determinants of vegetation formation [5] and growth that are linked to septic thrombus formation, including platelet activation and aggregation [6] and fibrin-fibronectin deposition $[7,8]$.

Previous studies have shown that platelet activation occurs in patients with infective endocarditis [9-11]. The mean platelet volume (MPV) is an indicator of platelet activation and is important in the pathophysiology of cardiovascular disease $[12,13]$. MPV is an important and easily obtainable biological variable and larger platelets have higher thrombotic potential [14]. In comparison to smaller ones, larger platelets have more granules, aggre- 
gate more rapidly with collagen, have higher thromboxane A2 levels and express more glycoprotein Ib and IIb/ IIIa receptors [15-17]. Because of these important factors, we investigated MPV, an indicator of platelet activation in patients with infective endocarditis, and change in MPV values after treatment.

\section{Subjects and Methods}

Twenty-nine consecutive patients (19 M/10 F; mean age 56.2 \pm 19.3 years, range 22-80) were studied between December 2005 and January 2010, with 29 control subjects $(20 \mathrm{M} / 9 \mathrm{~F}$; mean age $49.9 \pm 12.1$ years, range $32-67)$. All patients were hospitalized for infective endocarditis. Nine patients had prosthetic heart valves and 4 of them had pacemakers previously. All cases of left-sided infective endocarditis defined according to Duke criteria [18] with later modifications [19] for definite and possible infective endocarditis were included in the study. All patients initially received empiric antibiotic therapy containing ampicillin sulbactame and gentamicin. The choice of antimicrobial agents was made on the basis of culture results or, in the case of culture-negative endocarditis, on an empirical basis. Treatment was given during a 2-week hospital stay and if clinical status was stable, patients were discharged from hospital and oral ampicillin sulbactame were continued for at least 4 weeks according to ESCAHA guidelines. Second blood samples for MPV levels were collected after 2 weeks of specific treatment of infective endocarditis. Exclusion criteria were left ventricular dysfunction, acute coronary syndromes, lung disease and chronic renal or hepatic diseases. No patients were using lipid lowering drugs. The protocol conformed to the ethical guidelines of our institution and informed consent was obtained from each participant.

\section{Blood Sampling}

Blood samples were drawn for blood culture from the antecubital vein by puncture in a $21 \mathrm{G}$ sterile syringe without stasis. Patients' MPV, white blood cell, hemoglobin, glucose, creatinine levels and lipid profiles were also evaluated for analysis. The venous peripheral blood samples for MPV measurements were drawn on admission and 2 weeks after treatment. MPV was measured in a blood sample collected in dipotassium EDTA tubes within $30 \mathrm{~min}$ after blood collection to prevent EDTA-induced swelling. An automatic blood counter (Beckman Coulter, Fullerton, Calif., USA) was used for whole blood counts. Glucose, creatinine and lipid profiles were measured with an auto analyzer (Olympus AU 640).

\section{Statistical Analysis}

Data were analyzed with the SPSS software version 15.0 for Windows (SPSS Inc., Chicago, Ill., USA). Data are expressed as mean \pm standard deviation. The Kolmogorov-Smirnov test was used to test the distribution of numeric variables. To compare continuous variables, the Student t test or Mann-Whitney U test was used as appropriate. Because glucose levels can influence MPV values, glucose was taken as a covariate and covariate analysis (ANCOVA) was performed for MPV comparison. Categorical variables were compared with the $\chi^{2}$ test. To compare continuous variables before and after treatment, a paired sample t test was used. Statistical significance was defined as $\mathrm{p}<0.05$.
Table 1. Comparison of the clinical and laboratory characteristics of the study and control groups

\begin{tabular}{|c|c|c|c|}
\hline & $\begin{array}{l}\text { Patients } \\
(n=29)\end{array}$ & $\begin{array}{l}\text { Control } \\
(\mathrm{n}=29)\end{array}$ & $\begin{array}{l}\mathrm{p} \\
\text { value }\end{array}$ \\
\hline Age, years & $56.2 \pm 19.3$ & $49.9 \pm 12.1$ & 0.11 \\
\hline Male & $56.0 \pm 20.0$ & $48.9 \pm 11.8$ & 0.16 \\
\hline Female & $56.7 \pm 19.1$ & $52.2 \pm 13.7$ & 0.53 \\
\hline Male/female & $19 / 10$ & $20 / 9$ & 0.41 \\
\hline Hypertension & $6(20.7)$ & $7(24.1)$ & 0.12 \\
\hline \multicolumn{4}{|l|}{ Medications } \\
\hline ACEi/ARB & $5(17.2)$ & $4(13.7)$ & 0.71 \\
\hline CCB & $1(3.4)$ & $3(10.3)$ & 0.30 \\
\hline Smoking & $3(10.3)$ & $4(13.8)$ & 0.46 \\
\hline Obesity & $4(13.8)$ & $5(17.2)$ & 0.06 \\
\hline Glucose, mg/dl & $114.5 \pm 31.8$ & $88.4 \pm 9.89$ & $<0.01$ \\
\hline Creatinine, $\mathrm{mg} / \mathrm{dl}$ & $1.02 \pm 0.21$ & $0.89 \pm 0.25$ & 0.11 \\
\hline Total cholesterol, mg/dl & $124.0 \pm 25.0$ & $182.8 \pm 36.7$ & $<0.01$ \\
\hline Triglycerides, mg/dl & $135.5 \pm 72.5$ & $114.2 \pm 63.1$ & 0.32 \\
\hline LDL cholesterol, mg/dl & $70.1 \pm 24.1$ & $109.8 \pm 34.9$ & $<0.01$ \\
\hline HDL cholesterol, mg/dl & $28.3 \pm 9.4$ & $48.1 \pm 12.0$ & $<0.01$ \\
\hline Hemoglobin, g/dl & $12.4 \pm 1.3$ & $13.9 \pm 1.7$ & 0.01 \\
\hline Platelet count, $\times 10^{9}$ & $193.4 \pm 96.5$ & $213.1 \pm 39.5$ & 0.32 \\
\hline MPV, fl & $9.86 \pm 1.1$ & $8.0 \pm 1.0$ & $<0.01$ \\
\hline
\end{tabular}

Figures in parentheses are percentages. $\mathrm{p}$ value is for comparison between control and study population. LDL = Low-density lipoprotein; HDL = high-density lipoprotein; ACEi = angiotensin-converting enzyme inhibitor; $\mathrm{ARB}=$ angiotensin receptor blocker; $\mathrm{CCB}=$ calcium channel blocker.

\section{Results}

The clinical and laboratory characteristics of the study population and the control subjects are presented in table 1 . There were no statistically significant differences between the two groups with respect to age, gender, history of hypertension, smoking status, obesity and levels of creatinine, triglyceride and platelet count. MPV was found to be normally distributed $(\mathrm{p}=0.38)$. Fasting glucose levels of $114.5 \pm 31.8$ versus $88.4 \pm 9.89 \mathrm{mg} / \mathrm{dl}(\mathrm{p}<$ $0.01)$ and MPV values of $9.86 \pm 1.1$ versus $8.0 \pm 1.0 \mathrm{fl}$ $(\mathrm{p}<0.01)$ were significantly higher in patients with infective endocarditis than in controls. The covariate analysis (ANCOVA) on effect of glucose levels on MPV did not show any effect on MPV $(\mathrm{p}=0.21)$. Total cholesterol 124.0 \pm 25.0 versus $182.8 \pm 36.7 \mathrm{mg} / \mathrm{dl}(\mathrm{p}<0.01)$, low-density lipoprotein cholesterol $70.1 \pm 24.1$ versus $109.8 \pm 34.9$ $\mathrm{mg} / \mathrm{dl}(\mathrm{p}<0.01$ ), high-density lipoprotein cholesterol $28.3 \pm 9.4$ versus $48.1 \pm 12.0 \mathrm{mg} / \mathrm{dl}(\mathrm{p}<0.01)$ and hemoglobin levels $12.4 \pm 1.3$ versus $13.9 \pm 1.7 \mathrm{~g} / \mathrm{dl}(\mathrm{p}=$ 
Table 2. Comparison of the hematological parameters of the study population before and after treatment

\begin{tabular}{lccr}
\hline & $\begin{array}{l}\text { Before } \\
\text { treatment }\end{array}$ & $\begin{array}{l}\text { After } \\
\text { treatment }\end{array}$ & p value \\
\hline WBC, $\times 10^{3}$ & $11.8 \pm 5.8$ & $10.1 \pm 4.6$ & 0.07 \\
Hemoglobin, g/dl & $10.6 \pm 1.8$ & $10.4 \pm 1.6$ & 0.42 \\
Platelet count, $\times 10^{9}$ & $193.4 \pm 96.5$ & $243.7 \pm 92.4$ & 0.04 \\
MPV, fl & $9.86 \pm 1.1$ & $7.86 \pm 1.0$ & $<0.01$ \\
\hline
\end{tabular}

$\mathrm{p}$ value is for comparison between parameters before and after treatment. $\mathrm{WBC}=$ White blood cells.

0.01) of the infective endocarditis patients were significantly lower in the control group. Comparisons of the hematological parameters of the study population before and after treatment are shown in table 2. MPV values decreased significantly after treatment, from the active period of the disease to recovery $(9.86 \pm 1.1$ to $7.86 \pm 1.0$ $\mathrm{fl} ; \mathrm{p}<0.01)$. The total platelet counts of patients increased significantly after treatment for infective endocarditis $\left(193.4 \pm 96.5 \times 10^{9}\right.$ vs. $\left.243.7 \pm 92.4 \times 10^{9}, \mathrm{p}=0.04\right)$. There were no significant differences of the other hematological and biochemical parameters, including hemoglobin, white blood cell, glucose, creatinine and lipid profiles, in patients before and after treatment.

\section{Discussion}

The MPV was significantly higher in patients with infective endocarditis when compared with control subjects thereby implicating platelet activation in patients with infective endocarditis as previously reported [10]. Our finding that MPV values decreased significantly after treatment also confirmed the previous finding of Gunebakmaz et al. [20].

MPV has recently become an active area in cardiovascular research. It is a simple and easy laboratory measurement of assessing platelet function $[12,21]$ because it can be measured in almost all laboratories. Platelets are heterogeneous in size, density and reactivity. In comparison to smaller ones, larger platelets have more granules, aggregate more rapidly with collagen, have higher thromboxane A2 level and express more glycoprotein Ib and IIb/IIIa receptors [14, 16, 17].

The reason for increased MPV in infective endocarditis is not exactly known. There are a number of probable causes. Firstly bacteria-platelet interactions might play a critical role in platelet activation and thrombus formation in infective endocarditis [4-6]. Direct or indirect binding of bacteria to platelets can provoke their activation and aggregation, resulting in fibrin formation $[5,22]$. Secondly, it has been shown that serum levels of IL6, IL$1 \beta$ and C-reactive protein were significantly elevated in patients with infective endocarditis as compared to controls [23]. Elevated inflammatory cytokines such as IL-3 and IL- 6 can lead to the production of more reactive and larger platelets as reported previously [24]. Hence, elevated levels of IL- 6 in infective endocarditis might be a cause of increased MPV. Thirdly, endothelial injury due to bacterial toxins, hemodynamic forces and autoimmune reactions might lead to platelet activation and consequently increased MPV in infective endocarditis. It has been reported that once endothelial injury occurs, it leads to the denudation of the vessel wall, hence the local antithrombotic function of the endothelium cannot be maintained and local thrombosis with the formation of vegetations occur immediately [25].

Thrombocytopenia in critically ill patients on admission has been recognized as a poor prognostic sign [26, 27] and is associated with a higher relative risk of mortality in septic patients [26]. We found lower platelet count in patients with infective endocarditis than the control group and platelet count increased significantly after treatment.

The limitations of this study include the small number of patients and that the analysis was based on a simple baseline determination that may not reflect the patient status over long periods. Also, even though age difference was not statistically different, the range of age was narrower in the control subjects and the control group was not also followed up and compared.

\section{Conclusion}

In this study, MPV values were significantly higher among patients with infective endocarditis when compared with the control group and the values decreased significantly after treatment. Elevated MPV indicated that patients with infective endocarditis have an increased platelet activation and infective endocarditis treatment decreased platelet activation. We recommend further prospective studies in order to establish the pathophysiological and clinical significance of increased MPV in patients with infective endocarditis. 


\section{References}

$>1$ Hoen B, Alla F, Selton-Suty C, Béguinot I, Bouvet A, Briançon S, Casalta JP, Danchin N, Delahaye F, Etienne J, et al: Changing profile of infective endocarditis: results of a 1-year survey in France. JAMA 2002;3;288:75-81.

$>2$ Ferreiros E, Nacinovich F, Casabé JH, Modenesi JC, Swieszkowski S, Cortes C, Hernan CA, Kazelian L, Varini S: Epidemiologic, clinical, and microbiologic profile of infective endocarditis in Argentina: a national survey: the Endocarditis Infecciosa en la Republica Argentina-2 (EIRA-2) Study. Am Heart J 2006;151:545-552.

-3 Moreillon P, Que YA: Infective endocarditis. Lancet 2004;363:139-149.

$\checkmark 4$ Widmer E, Que YA, Entenza JM, Moreillon P: New concepts in the pathophysiology of infective endocarditis. Curr Infect Dis Rep 2006;8:271-279.

$>5$ Fitzgerald JR, Foster TJ, Cox D: The interaction of bacterial pathogens with platelets. Nat Rev Microbiol 2006;4:445-457.

6 Yeaman MR: The role of platelets in antimicrobial host defense. Clin Infect Dis 1997;25: 951-968.

7 Schwarz-Linek U, Werner JM, Pickford AR, Gurusiddappa S, Kim JH, Pilka ES, Briggs JA, Gough TS, Höök M, Campbell ID, et al: Pathogenic bacteria attach to human fibronectin through a tandem beta-zipper. Nature 2003;423:177-181.

$>8$ Que YA, Haefliger JA, Piroth L, François P, Widmer E, Entenza JM, Sinha B, Herrmann M, Francioli P, Vaudaux P, et al: Fibrinogen and fibronectin binding cooperate for valve infection and invasion in Staphylococcus aureus experimental endocarditis. J Exp Med 2005;20:1627-1635.

$\checkmark 9$ Rouzet F, Dominguez Hernandez M, Hervatin F, Sarda-Mantel L, Lefort A, Duval X, Louedec L, Fantin B, Le Guludec D, Michel JB: Technetium 99m-labeled annexin V scintigraphy of platelet activation in vegetations of experimental endocarditis. Circulation 2008;117:781-789.
10 Ileri M, Alper A, Senen K, Durmaz T, Atak R, Hisar I, Yetkin E, Turhan H, Demirkan D: Effect of infective endocarditis on blood coagulation and platelet activation and comparison of patients with to those without embolic events. Am J Cardiol 2003;91:689-692.

-11 Buyukasik NS, Ileri M, Alper A, Senen K, Atak R, Hisar I, Yetkin E, Turhan H, Demirkan D: Increased blood coagulation and platelet activation in patients with infective endocarditis and embolic events. Clin Cardiol 2004;27:154-158.

12 Park Y, Schoene N, Harris W: Mean platelet volume as an indicator of platelet activation: methodological issues. Platelets 2002;13: 301-306.

13 Tsiara S, Elisaf M, Jagroop IA, Mikhailidis DP: Platelets as predictors of vascular risk: is there a practical index of platelet activity? Clin Appl Thromb Hemost 2003;9:177-190.

14 Martin JF: Platelet heterogeneity in vascular disease; in Martin JF, Trowbridge EA (eds): Platelet Heterogeneity: Biology and Pathology. London, Springer, 1990, pp 205-226.

15 Martin JF, Trowbridge EA, Salmon G, Plumb $\mathrm{J}$ : The biological significance of platelet volume: its relationship to bleeding time, platelet thromboxane $\mathrm{B} 2$ production and megakaryocyte nuclear DNA concentration. Thromb Res 1983;32:443-460.

16 Jakubowski JA, Thompson CB, Vaillancourt R, Valeri CR, Deykin D: Arachidonic acid metabolism by platelets of differing size. Br J Haematol 1983;53:503-511.

17 Giles H, Smith RE, Martin JF: Platelet glycoprotein IIb-IIIa and size are increased in acute myocardial infarction. Eur J Clin Invest 1994;24:69-72.

18 Durack DT, Lukes AS, Bright DK: New criteria for diagnosis of infective endocarditis: utilization of specific echocardiographic findings. Duke Endocarditis Service. Am J Med 1994;96:200-209.
19 Prendergast BD: Diagnostic criteria and problems in infective endocarditis. Heart 2004;90:611-613.

20 Gunebakmaz O, Kaya MG, Kaya EG, Ardic I, Yarlioglues M, Dogdu O, Kalay N, Akpek M, Sarli B, Ozdogru I: Mean platelet volume predicts embolic complications and prognosis in infective endocarditis. Int J Infect Dis 2010;14:982-985.

21 Boos CJ, Lip GY: Assessment of mean platelet volume in coronary artery disease - what does it mean? Thromb Res 2007;120:11-13.

22 Arvand M, Bhakdi S, Dahlback B, Preissner KT: Staphylococcus aureus alpha-toxin attack on human platelets promotes assembly of the prothrombinase complex. J Biol Chem 1990;265:14377-14381.

23 Watkin RW, Harper LV, Vernallis AB, Lang S, Lambert PA, Ranasinghe AM, Elliott TS: Pro-inflammatory cytokines IL6, TNF$\alpha$, IL1 $\beta$, procalcitonin, lipopolysaccharide binding protein and C-reactive protein in infective endocarditis. J Infect 2007;55:220205.

24 Debili N, Masse JM, Katz A, Guichard J, Breton-Gorius J, Vainchenker W: Effects of the recombinant hematopoietic growth factors interleukin-3, interleukin-6, stem cell factor, and leukemia inhibitory factor on the megakaryocytic differentiation of CD34+ cells. Blood 1993;82:84-95.

25 Chorianopoulos E, Bea F, Katus HA, Frey N: The role of endothelial cell biology in endocarditis. Cell Tissue Res 2009;335:153-163.

26 Sprung CL, Peduzzi PN, Shatney CH, Schein RM, Wilson MF, Sheagren JN, Hinshaw LB: Impact of encephalopathy on mortality in the sepsis syndrome. The Veterans Administration Systemic Sepsis Cooperative Study Group. Crit Care Med 1990;18:801-806.

$\checkmark 27$ Baughman RP, Lower EE, Flessa HC, Tollerud DJ: Thrombocytopenia in the intensive care unit. Chest 1993;104:1243-1247. 